\title{
PROMOSI KESEHATAN KERJA PADA PENGRAJIN TENUN
}

\author{
Ratna Indriawati ${ }^{1}$, Idiani Darmawati ${ }^{11}$ \\ 1)Program Studi Pendidikan Dokter, Universitas Muhammadiyah Yogyakarta, Yogyakarta, Indonesia \\ Corresponding author: Ratna Indriawati \\ E-mail : r_indriawatiwibowo@yahoo.com
}

\section{Diterima 14 Januari 2021, Direvisi 16 Maret 2021, Disetujui 17 Maret 2021}

\begin{abstract}
ABSTRAK
Masalah kesehatan kerja mempengaruhi individu, keluarga dan masyarakat. Pengabdian masyarakat ini bertujuan untuk menambah pengetahuan kesehatan kerja, dampak kerja terhadap kesehatan serta pencegahannya. Disamping itu juga untuk menambah wawasan para pekerja mengenai pentingnya penerapan budaya kesehatan dan keselamatan kerja (K3) di tempat kerja serta menciptakan kondisi tempat kerja yang aman dan nyaman bagi para pekerja. Metode pengabdian masyarakat menggunakan promosi dan edukasi kesehatan kerja. Sasaran program pengabdian masyarakat ini adalah 15 orang pengrajin tenun Sejati Desa. Kegiatan pengabdian masyarakat ini meliputi : pembuatan media promosi kesehatan (leaflet); Edukasi dan promosi kesehatan kerja; evaluasi kegiatan dengan tanya jawabHasil pengabdian masyarakat ini menunjukkan adanya tambahan pengetahuan pekerja tenun terkait kesehatan kerja. Promosi kesehatan kerja masih diperlukan untuk menambah pengetahuan kesehatan kerja.
\end{abstract}

Kata kunci: kesehatan; kerja; pengetahuan; tenun

\begin{abstract}
Occupational health problems affect individuals, families and communities. This community service aims to increase knowledge of occupational health, the impact of work on health and its prevention. Besides that, it is also to increase the knowledge of workers about the importance of implementing a culture of occupational health and safety (K3) in the workplace and creating safe and comfortable workplace conditions for workers. Community service methods use promotion and occupational health education. The target of this community service program is 15 Sejati Desa weaving craftsmen. These community service activities include: making health promotion media (leaflets); Occupational health education and promotion; evaluation of activities with discussion. The results of this community service show that weaving workers have additional knowledge regarding occupational health. Occupational health promotion is still needed to increase occupational health knowledge.
\end{abstract}

Keywords: health; work; knowledge; weaving

\section{PENDAHULUAN}

Kesehatan kerja merupakan hal yang perlu mendapat perhatian. Pekerja yang sehat tidak hanya untuk kepentingan individu pekerja sendiri tetapi juga berkaiatan erat dengan kebahagiaan keluarga. Selanjutnya akan berpengaruh pada masyarakat. Masalah keselamatan dan Kesehatan kerja di Indonesia mendapat perhatian dan dukungan dari pemerintah. Peraturan perundangan undangan tentang keselamatan kerja adalah UndangUndang Keselamatan Kerja Nomor 1 Tahun 1970. Keselamatan kerja telah ditingkatkan untuk mencapai kecelakaan nihil (zero accident) pada setiap proses produksi sejak tahun 1993 (Aria et al., 2015).

Keselamatan dan Kesehatan Kerja (K3) sangat diperlukan. Faktor kuat yang sering menyebabkan terjadinya kecelakaan kerja dan penyakit terhadap buruh/pekerja yang selama ini bekerja di perusahaan adalah karena lemahnya penerapan standar K3 di perusahaan. Penerapan K3 yang lemah berdampak kepada lingkungan sosial masyarakat sekitar. Banyak pekerja yang mengalami kecelakaan kerja akibat faktor perilaku tindakan tidak aman (unsafe action) dalam bekerja. Hal ini disebabkan karena kurangnya pengetahuan pekerja tentang K3. Cara mengurangi kecelakaan kerja dan gangguan kesehatan yang berdampak tidak baik pada buruh/pekerja dalam perusahaan adalah standar K3 harus dilaksanakan (Pradana \& Djastuti, 2015).

Jenis alat dan sarana kerja yang kurang nyaman sering menimbulkan masalah-masalah kesehatan pada pekerja yang menggunakanya, jika digunakan dalam jangka waktu yang lama dalam per-harinya memberikan efek negatif 
pada kesehatan yang memicu timbulnya penyakit akibat hubungan kerja (Cris, 2012).

Edukasi dan Promosi kesehatan merupakan program kesehatan yang dirancang untuk mempengaruhi individu, dan masyarakat, sehingga berfikir, bersikap, dan berperilaku positif tujuannya untuk meningkatkan kesehatan, edukasi kesehatan adalah upaya untuk memelihara, meningkatkan, dan kesehatan diri dan lingkungan. Secara umum edukasi kesehatan bertujuan untuk mengembangkan perilaku individu, kelompok, atau masyarakat agar bisa berperilaku hidup bersih dan sehat, dan terhindar dari penyakit (Indriawati \& Usman, 2018) (Aria et al., 2015). Memberikan tiga indikator pembangunan manusia yang disusun dalam Human Development Index atau Indeks Pembangunan Manusia yakni pengetahuan, kesehatan, dan ekonomi. Ketiga hal tersebut bukan hanya saling terkait dan mempengaruhi, namun juga saling melengkapi dalam membentuk kualitas hidup manusia (Elvidge et al., 2012) (Suparmi et al., 2018) (Indriawati \& Syaifudin, 2020).

Pengabdian masyarakat ini bertujuan untuk meningkatkan pengetahuan kesehatan kerja, dampak kerja terhadap kesehatan serta pencegahannya. Disamping itu juga untuk menambah wawasan para pekerja mengenai pentingnya penerapan budaya kesehatan dan keselamatan kerja (K3) di tempat kerja serta menciptakan kondisi tempat kerja yang aman dan nyaman bagi para pekerja.

\section{METODE}

Promosi kesehatan kerja dilakukan di desa wisata Sejati Desa, Moyudan, Yogyakarta. Peserta berjumlah 15 orang pengrajin tenun Sejati Desa. Metode yang digunakan adalah penyuluhan melalui ceramah dan diskusi. Pengabdian masyarakat ini telah dilaksanakan pada tanggal 11 Februari 2021. Kegiatan pengabdian meliputi beberapa langkah. Kegiatan pengabdian yang yang merupakan langkah-langkah solusi atas persoalan adalah sebagai berikut:

1.Persiapan. Tahap persiapan yang dilakukan adalah tim pengabdian bersama dengan mitra menyusun rencana kegiatan, pendataan dan semua kebutuhan terkait pelaksanaan kegiatan.

2.Tahap Pelaksanaan. Tahap pelaksanaan dilakukan beberapa aktifitas. Kegiatan ini dibagi menjadi 2 aktifitas yaitu:

2.1. Pembuatan media promosi kesehatan (leaflet). Leaflet yang sudah siap kemudian dicetak dan dibagiakan ke sasaran program pengabdian

masyarakat. Sasaran program pengabdian masyarakat ini adalah pengrajin tenun Sejati Desa, Moyudan, Yogyakarta.

2.2. Penyuluhan kesehatan kerja.

Penyuluhan kesehatan kerja dilakukan dengan memperhatikan protocol kesehatan COVID-19. Penyuluhan menggunakan metode ceramah. Setelah materi pengabdian selesai dipaparkan, kemudian dilanjutkan dengan diskusi dengan peserta penyuluhan.

3. Tahap evaluasi dan dokumentasi

Evaluasi kegiatan pengabdian masyarakat untuk menilai apakah promosi kesehatan kerja ini menarik dan bermanfaat bagi sasaran program pengabdian masyarakat. Disamping itu sebagai rekomendasi sesuai temuan yang didapatkan sehingga pelaksanaan berikutnya bisa berjalan lebih baik. Data pelaksanaan kegiatan pengabdian masyarakat didokumentasi baik berupa foto, media pengabdian dan hal-hal terkait pengabdian masyarakat ini.

\section{HASIL DAN PEMBAHASAN}

Pelaksanaan kegiatan pengabdian masyarakat ini meliputi beberapa tahap. Media promosi kesehatan kerja yang digunakan pada pengabdian masyarakat ini adalah leaflet, ceramah dan diskusi. Leaflet meruakan media yang praktis dan menarik untuk promosi kesehatan. Keunggulan lain dari leaflet adalah tulisan singkat tapi informatif, ada gambar dan skema yang menarik, mudah dibawa dan disimpan, ringkas (Saleh \& Kunoli, 2019)(Wantania et al., 2018). Pelaksanaan promosi kesehatan dengan media leaflet dapat dilihat pada Gambar 1. Peserta antusis dan aktif mengikuti kegiatan tersebut. 


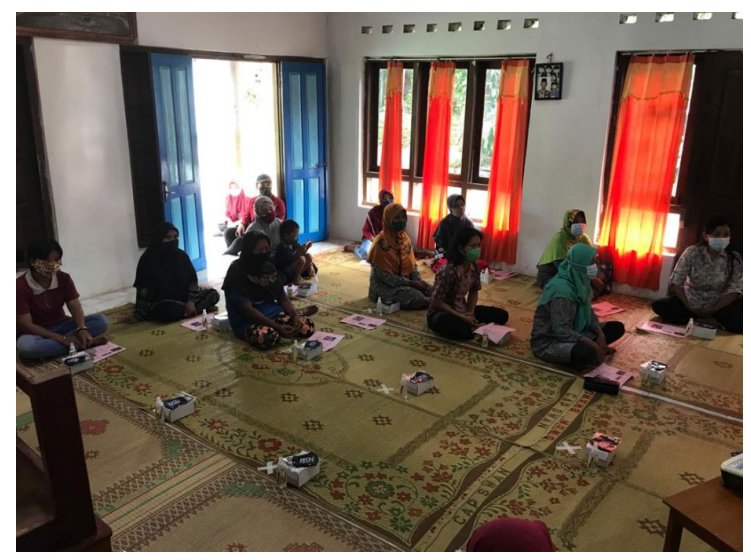

Gambar 1. Peserta Promosi Kesehatan Kerja

Pelaksanaan promosi kesehatan ini masih dalam kondisi pandemi COVID-19. Protokol kesehatan pencegahan COVID-19 harus digunakan (Ibrahim et al., 2020). Perserta wajib pakai masker, jaga jarak, cuci tangan sesuai protokol kesehatan pencegahan COVID-19. Jumlah peserta juga dibatasi.

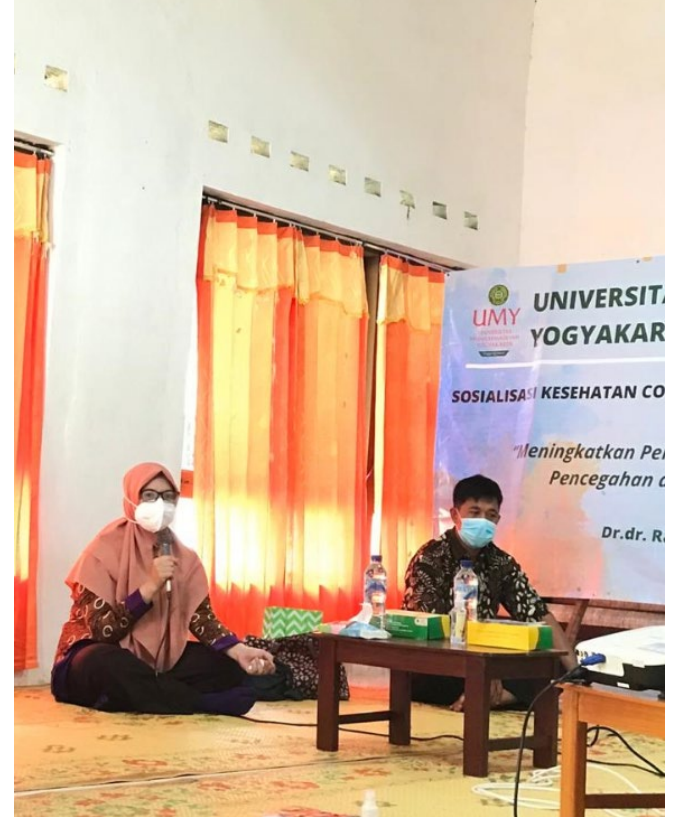

Gambar 2. Pemateri Promosi Kesehatan Kerja

Kegiatan promosi kesehatan kerja selanjutnya adalah melalui ceramah dan diskusi (Gambar 2). Ceramah untuk menyampaikan materi promosi kesehatan kepada pengrajin tenun Sejati dilakukan interaktif. Peserta tertarik dan responsif. Setelah materi promosi selesai dipaparkan, dilanjutkan dengan diskusi dan tanya jawab. Peserta aktif bertanya. Beberapa pertanyaan yang disampaikan. Pertanyaan peserta antara lain tentang keluhan pegal saat dan setelah menenun. Dampak posisi yang menetap (statis) dalam waktu lama saat menenun dapat menimbulkan gangguan kesehatan antara lain myalgia, low back pain (Kerja et al., 2013) (Wirawan et al., 2016). Secara umum kegiatan promosi kesehatan kerja ini berjalan baik dan lancar.

\section{SIMPULAN DAN SARAN}

Promosi kesehatan kerja dapat menambah pengetahuan kesehatan kerja, dampak kerja terhadap kesehatan serta pencegahannya. Hasil evaluasi kegiatan melalui tanya jawab dengan peserta menunjukkan tambahan pengetahuan kesehatan kerja pada peserta pengabdian masyarakat. Disamping itu juga untuk menambah wawasan para pekerja mengenai pentingnya penerapan budaya kesehatan dan keselamatan kerja (K3) di tempat kerja.

\section{UCAPAN TERIMAKASIH}

Penulis mengucapkan terimakasih kepada Lembaga Penelitian dan Pengabdian Masyarakat (LPPM) Universitas Muhammadiyah Yogyakarta atas hibah dana Pengabdian Masyakat yang telah diberikan..

\section{DAFTAR RUJUKAN}

Aria, T., Utami, H., \& Mayowan, Y. (2015). PENGARUH KESELAMATAN DAN KESEHATAN KERJA TERHADAP KEPUASAN KERJA KARYAWAN (Studi pada Karyawan bagian Produksi PT Hankook Tire Indonesia, Cikarang). Jurnal Administrasi Bisnis S1 Universitas Brawijaya, 29(1), 112-120.

Elvidge, C. D., Baugh, K. E., Anderson, S. J., Sutton, P. C., \& Ghosh, T. (2012). The Night Light Development Index (NLDI): A spatially explicit measure of human development from satellite data. Social Geography, 7(1), 23-35. https://doi.org/10.5194/sg-7-23-2012

Ibrahim, Kamaluddin, Mas'ad, AM, M., Gani, J., \& Abd, A. (2020). Bencana Virus Corona Melalui Sosialisasi Pada Anak Usia Dini. Jurnal Pengabdian Masyarakat Berkemajuan, 3(2), 191195.

Indriawati, R., \& Syaifudin, S. (2020). Relationship between Demographic Factors and Body Mass Index with the Prevention of Hypertension in Adolescents. Journal of Health Promotion and Behavior, 5(2), 72-78. https://doi.org/10.26911/thejhpb.2020. 05.02.01

Indriawati, R., \& Usman, S. (2018). Pemberdayaan Masyarakat sebagai Upaya Deteksi Dini Faktor Risiko 
Hipertensi. Jurnal Surya Masyarakat, 1(1),

59. https://doi.org/10.26714/jsm.1.1.2018. 59-63

Kerja, M., Sikap, D. A. N., Duduk, K., \& Nyeri, T. (2013). Masa Kerja Dan Sikap Kerja Duduk Terhadap Nyeri Punggung. Jurnal Kesehatan Masyarakat, 9(1), 914. https://doi.org/10.15294/kemas.v9i1.28 24

Saleh, A., \& Kunoli, F. J. (2019). Pengaruh Penyuluhan Dan Pelatihan Melalui Media Leaflet Terhadap Pengetahuan Kader Phbs Di Kecamatan Ratolindo Kabupaten Tojo Una-Una. PROMOTIF: Jurnal Kesehatan Masyarakat, 8(2), 159-164.

https://doi.org/10.31934/promotif.v8i2. 498

Suparmi, Kusumawardani, N., Nambiar, D., Trihono, \& Hosseinpoor, A. R. (2018). Subnational regional inequality in the public health development index in Indonesia. Global Health Action, 11(sup1).

https://doi.org/10.1080/16549716.2018 .1500133

Wantania, J. S., Laenggeng, A. H., Moonti, S., Promkes, B., Masyarakat, K., \& Palu, U. M. (2018). Pendidikan Kesehatan Melalui Media Leaflet Tentang Perilaku Hidup Bersih Dan Sehat (Phbs) Terhadap Pengetahuan Kader Kesehatan Di Wilayah Kerja Puskesmas Donggala Health Education Through the Media Leaflet on Behavior and Healthy Life on Health Cadre'S In. Jurnal Kolaboratif Sains, 1(1), 382-388.

Wirawan, A., Muliawan, P., \& Duana, I. M. K. (2016). Laporan Pengabdian Penyuluhan K3 di Pabrik Cakra Batik Program Studi Kesehatan Masyarakat. 1-7.

Cris, P. (2012). Masa Kerja, Sikap Kerja dan Kejadian Sindrom Karpal pada Pembatik. Jurnal Ke-mas, 7(2): 170176

Pradana, A. A., \& Djastuti. (2015). Implementasi Program Keselamatan dan Kesehatan Kerja serta Tantangan yang akan dihadapi PT PLN (Persero) PLTU TJB Jepara Dalam Upaya Mempertahankan Zero Accident. 4, 1-15. https://doi.org/10.1146/annurev.polisci. 7.012003.104840 